\title{
Teoretické dílo Miloše Wasserbauera v kontextu dobového myšlení o operní inscenační tvorbě
}

\section{Theoretical Work of Miloš Wasserbauer In Relation \\ To The Contemporary Thinking About Staging Opera}

Šárka Havlíčková Kysová

\begin{abstract}
Abstrakt
Studie se zabývá teoretickým dílem českého operního režiséra Miloše Wasserbauera (1907-1970). Wasserbauerovy úvahy o operně inscenační praxi byly publikovány převážně v 50. a 60. letech 20. století v českých periodicích či v programech kinscenacím, které režíroval. Několik textů se dochovalo pouze v podobě rukopisu v jeho pozůstalosti, uložené $\checkmark$ oddělení dějin divadla Moravského zemského muzea. Na základě těchto pramenů a ohlasů Wasserbauerovy režijní tvorby $v$ tisku se snažíme vyložit jeho názory na operně inscenační praxi v kontextu doby. Wasserbauerovy myšlenky jsou ve studii sdruženy do pěti tematických okruhů: partitura jako východisko režijně-dramaturgické koncepce inscenace; otázka realizmu jako inscenačního stylu v opeře; herecká práce při vzniku inscenace; problematika soudobé opery a inscenování oper Leoše Janáčka.
\end{abstract}

\section{Klíčová slova}

Miloš Wassebauer; Státní divadlo v Brně; opera; operní režie; idea díla; vycházení z partitury

\begin{abstract}
The study deals with theoretical writings of Miloš Wasserbauer (1907-1970), Czech opera director. Wasserbauer's articles on opera staging were being published in Czech periodicals and programmes to productions he directed mostly in 1950s and 1960s; several texts are extant as manuscripts in his estate kept by the Theatre Department of Moravian Museum, Brno. Based on these materials and print contemporary references to Wasserbauer's productions, the author strives to grasp and analyse his views on staging operatic pieces. Wasserbaure's ideas on the issue are grouped as follows: the score as a departing point for directorialdramaturgical concept; realism in staging opera; acting as a part of rehearsal process; staging operas by Leoš Janáček.
\end{abstract}

\section{Keywords}

Miloš Wasserbauer; Státní divadlo, Brno; opera; opera direction; ideology of an operatic piece; the score

Studie vznikla v rámci grantového projektu GA15-06548S "Generace režiséra Miloše Wasserbauera a progresívní dramaturgie v opeře Státního divadla v Brně". 
Miloš Wasserbauer (1907-1970), důležitá osobnost brněnské operní režie, se pravidelně vyslovoval k teoretickým otázkám své profese. Činil tak zejména v programech k inscenacím, v dobových periodicích (např. v Programu Státního divadla, v Hostu do domu, v časopise Divadlo atd.) či v dosud nepublikovaných rukopisech. Kromě Wasserbauerových textů budeme v této studii vycházet i z dalších zdrojů - textů jiných autorů: např́klad statí uveřejněných v programech $\mathrm{k}$ Wasserbauerovým inscenacím, z rozhovorů s ním či z recenzí jeho inscenací. Z Wasserbauerových slov a samozřejmě i z reflexe jeho inscenací v dobovém tisku si lze učinit představu o jeho smýšlení o inscenační praxi opery i na obecnější úrovni. $\mathrm{Z}$ jeho četných textů, které jsou obvykle menšího rozsahu a málokdy přesahují pět stran, můžeme vyčíst jeho názory zejména na teoretické problémy operní režie. V této studii se zaměříme na pět hlavních témat, která Wasserbauera zajímala natolik, že se jim ve svých teoretických statích věnoval opakovaně. Prvním z nich je vycházeni z partitury při tvorbě režijně dramaturgické koncepce inscenace, druhým je otázka realizmu jako inscenačního stylu v opeře, třetí téma představuje okruh otázek týkající se herecké práce při vzniku inscenace. Další, čtvrtou oblastí, která přitahovala Wasserbauerovu pozornost, je problematika soudobé opery. Posledním tématem, na něž se $\mathrm{v}$ této studii zaměříme, jsou režisérovy úvahy o přístupu $\mathrm{k}$ inscenování oper Leoše Janáčka.

\section{Partitura jako východisko scénické interpretace operního díla}

\section{Ústřední idea díla a vycházení z partitury}

Základním požadavkem Wasserbauera v oblasti „správné“, tj. zejména nikoliv samoúčelné či svévolné, jevištní interpretace hudebně-dramatického díla je ústřední idea hudebně-dramatického díla, respektive její hledání a zprostředkování divákovi. To úzce souvisí s částečně metaforicky ale i doslovně chápanou proklamovanou metodou tvorby - vycházením z partitury. Partitura má sloužit jako základ jevištní interpretace operního díla.

Ústředni idea díla je zcela závislá na tom, zda inscenátoři naleznou vhodné scénické prostředky, které úspěšně vystihují autorův styl. Jednodušeji řečeno, za ústředni ideu považuje Wasserbauer důvod, proč ${ }^{11}$ skladatel operu psal (WASSERBAUER 1957: 212). Z této motivace vychází totiž konkrétní způsob hudebního ztvárnění, z něhož má pak vycházet také scénické provedení. Pojem idea díla se objevuje v řadě Wasserbauerových dokumentů obsahujících poznámky k připravované inscenaci. V rukopisech uložených v jeho pozůstalosti² se obvykle nachází jedna či dvě věty předznamenané právě pojmem „idea díla“. Režisér se v nich snaží co nejstručněji vyjádřit hlavní myšlenku či koncept opery, jenž do díla vložil již sám jeho autor (skladatel) či autoři (skladatel a libretista).

1 Z kontextu Wasserbauerových prací vyplývá, že měl na mysli hlavní sdělení či myšlenku díla, respektive základní dějový koncept.

2 Pozůstalost M. Wasserbauera je uložena v oddělení dějin divadla Moravského zemského muzea. Zde zmiňované přípravné dokumenty k inscenacím obsahující rukopisné (či řidčeji strojopisné) poznámky jsou uloženy v kartonu č. 280. 
Tak např́iklad u Verdiho Dona Carlose Wasserbauer zmiňuje „boj proti utlačovatelo̊m a reakční úlohu církve, která podpírá světskou vládu krále, nástroj své vlastní moci, a lid, mající už odvahu vzbouřit se proti králi, přinutí ještě na kolena před církví a její hrozbou věčného zatracení.“ Ideu Mozartovy Figarovy svatby vnímá jako „[b]oj Figara a Zuzky[,] představitelů poddaného lidu v době před velkou revolucí - za jejich lidské právo proti feudálnímu pánovi, pomocí zbraně v tehdejších historických podmínkách jedině možné: chytrostí, lstí a vtipem opřeným o vzájemnou stálost citů“. U Z mrtvého domu si Wasserbauer značí: „V každém tvoru jiskra boží (Pozůstalost MW, MZM, karton 280). Nutno podotknout, že u některých oper Wasserbauer neuvádí ideu díla, nýbrž ideu inscenace (doslova „našeho představení“ či „mé koncepce“). Například u Verdiho Sily osudu formuluje ideu své koncepce slovy „[r]asová a stavovská nenávist a jak se to stává osudnou silou v lidských tragédiích“ (Pozůstalost MW, MZM, karton 280). Z režisérových poznámek je tedy patrné, že rozlišuje mezi ideou (konceptem) díla a hlavní ideou své režijní interpretace. ${ }^{3}$

Badatelé se v kontextu pojednání o inscenacích vytvořených M. Wasserbauerem často uchylují právě k charakteristice režijní tvorby Miloše Wasserbauera pomocí již zmíněného „(důsledného) vycházení z partitury“. ${ }^{4}$ Wasserbauer sám v partituře hledá onu ústředni ideu díla a hudební partituru skutečně chápe jako rozhodující a určující základ veškerého scénického dění (WASSERBAUER 1957: 211).

Dana Toncrová ve své diplomové práci z roku 2000, již psala pod vedením Bořivoje Srby, věnované části Wasserbauerovy tvorby, upozornila na skutečnost, že princip „vycházení z partitury“ je v kontextu české operní režie staršího data. Hudební partituru jako základ jevištní interpretace operního díla totiž prosazoval již Ferdinand Pujman, jenž je pokládán za zakladatele české operní režie. Toncrová tvrdí, že „Wasserbauer souhlasil s Pujmanem v tom, že východiskem režijní práce má být podrobná znalost partitury, že se má skladatelův hudební styl stát určujícím činitelem výstavby všech složek do prokomponovaného, stylově jednotného celku. Praktický př́istup k tomuto požadavku se ovšem u obou výrazně lišil. Pujman nevytvářel své inscenace jako realistický obraz skutečnosti, ale jako vysoce stylizované dílo. Wasserbauer z partitury určoval ideu opery a umělecké prostředky jejího vyjádření, ale základem zůstával realistický pohled na zobrazovanou uměleckou skutečnost.“ (TONCROVÁ 2000: 15)

Miloš Wasserbauer se v době svých angažmá v Brně ${ }^{5}$ setkával při práci s řadou vynikajících dirigentů, mezi něž patřil mimo jiné i František Jílek. Tento dirigent se významně podílel na dramaturgickém směřování brněnské opery. Ostatně i Václav Nosek, který oficiálně zastával post dramaturga opery, byl profesí dirigent a jako dirigent byl divadlem angažován již v sezóně 1952/53. Tyto skutečnosti musely nutně formovat nejen

3 Tato problematika je však prozatím předmětem dalšího, nyní probíhajícího, výzkumu autorky této studie. Její výsledky budou zveřejněny v jiné stati.

4 Např. Olga Janáčková (1984) či Dana Toncrová (2000).

5 V Brně tvořil ve třech různých obdobích - již před druhou světovou válkou (od 1937 do zavření divadla za okupace) a potom v padesátých letech. Za nejvýznamnější lze považovat období jeho třetí práce ve Státním divadle v Brně, které trvalo od počátku 60. let až do jeho smrti v roce 1970. V letech 1943-1944 působil v Českém lidovém divadle v Brně, 1944-1946 byl angažován v Ostravě a 1953-1960 v Bratislavě (JANÁČKOVÁ 1984: 504). 
režijně dramaturgický styl konkrétních operních inscenací, včetně těch, na nichž se podílel Miloš Wasserbauer, ale také jeho myšlení o jevištní interpretaci operního díla.

Vycházení z partitury a hledání ideje díla se v praxi i teoretickém myšlení o opeře spojovalo s otázkou stylu inscenace, v té době konkrétně s realizmem, respektive s ideálem scénického realismu. Otázka realizmu se tedy v době, kdy Wasserbauer působil v brněnském Státním divadle, tj. zejména v padesátých a šedesátých letech 20. století, diskutovala v kontextu jevištní interpretace operního díla. Operní režie se vyrovnávala s odkazem K. S. Stanislavského, včetně jeho dezinterpretace pod vlivem soudobé ideologie, a také s působením Waltera Felsensteina, ${ }^{6}$ jehož práce ovlivňovala operní tvůrce za hranicemi jeho německého působiště.

\section{Ideál realismu v operní režii}

Svoje chápaní realizmu, respektive realistické scénické interpretace operního díla, formuloval Miloš Wasserbauer ve svém článku s názvem „Princip realistické scénické interpretace v opeře“ pro časopis Divadlo v roce 1957 (WASSERBAUER 1957). Svoje pojednání uvádí Wasserbauer odkazem na první díl Spisů Vissariona Grigorjeviče Bělinského ${ }^{7}$ a zdůrazňuje podstatu herecké tvorby, která dle Bělinského - a v návaznosti na něj i dle Wasserbauera - tkví ve věrné realizaci básníkem vytvořeného charakteru na jevišti (WASSERBAUER 1957: 211). Bělinský své pojetí realizmu přestavuje v kapitole „Hamlet, Shakespearovo drama. Močalov v úloze Hamleta“ (BĚLINSKIJ 1956). Wasserbauerův názor na hereckou tvorbu je formulován na základě Bělinského tvrzení, že „[d]ramatické básnictví je bez hereckého umění neúplné: abychom postavu dramatu plně pochopili, nestačí vědět, jak si počíná, mluví, cítí - je třeba též vidět a slyšet, jak si počíná, mluví a cítí.“ (BĚLINSKIJ 1956: 522) Tento Bělinského názor sice Wasserbauer ve svém článku necituje, avšak pravděpodobně z něho vychází, když zdůrazňuje tezi, že podstatou hercovy tvorby je schopnost „realisovat“ charakter již vytvořený básníkem (WASSERBAUER 1957: 211). ${ }^{8}$ Wasserbauer v této souvislosti zdůrazňuje rozdíl mezi interpretačním a tvůrčím, respektive produkčním uměním a rozdíl mezi jejich zaměřením. Vše vztahuje k opeře: „Operní interpretace realisuje svou tvorbou hudebně-dramatické dílo, v němž skladatel uměleckými prostředky vytvořil pravdivý odraz určité životní skutečnosti. [...] Odraz životní skutečnosti je v každém umění jen tehdy pravdivý, je-li utvářen uměleckými prostředky.“ (WASSERBAUER 1957: 211) Wasserbauer varuje jednak před mylným zaměňováním realistické scénické interpretace za naturalistické napodobování života, jednak před ztotožňováním realistické operní interpretace

6 Více o problematice realizmu hudebního divadla viz (HAVLÍČKOVÁ KYSOVÁ a SPURNÁ 2017).

7 Wasserbauer měl k dispozici pravděpodobně tehdy pouze rok staré vydání Bělinského knihy, která vyšla $\mathrm{v}$ roce 1956.

8 Za pozornost stojí skutečnost, že Bělinského stat’, z níž Wasserbauer ve svém textu cituje, vyšla v českém překladu (v rámci Spisů V. G. Bělinského) pouze rok před zveřejněním Wasserbauerova článku pro časopis Divadlo. 
s realistickým scénickým projevem ve smyslu činoherním. ${ }^{9}$ Onen „umělecký odraz“ skutečnosti, o němž Wasserbauer opakovaně hovoří, je vytvářen různými uměleckými prostředky, které jsou pro každý divadelní žánr zcela specifické. Opera tak dle jeho názoru nemůže být na scéně interpretována realisticky, pokud je „ve stylovém rozporu s podstatou slohového vyjádření skladatele“ (WASSERBAUER 1957: 211). Vyplývá to z vývoje opery jakožto žánru (či druhu), který má své specifické zákony, rozmanitou, historicky se vyvíjející formu, specifický styl a projev.

Pojem realismus dává Wasserbauer do souvislosti s uměleckou pravdou. Odlišuje ji od pravdy životní, přičemž obě „pravdy“ nestojí ve vzájemné opozici. Dle Wasserbauera pouze nejsou totožné, protože umělecká pravda tkví v pravdivosti uměleckého (operního) odrážení skutečnosti. To je založeno právě na oněch specifických zákonitostech opery (WASSERBAUER 1957: 211). Wasserbauer označuje jednotlivé složky (tj. herectví, scénografii atd.) jako scénický interpretačni sloh, tj. jednotící styl inscenace, který pramení v konkrétním historickém období a odpovídá hudebnímu stylu daného díla. Na př́k ladu tvorby Mozarta, Smetany a Janáčka Wasserbauer ukazuje „různorodost“ realizmu odlišných hudebně-dramatických děl. Tvrdí totiž, že právě ty podstatné znaky jisté historické (hudební) formy je třeba v inscenaci podtrhnout, nikoli snažit se je schovat či zcela odstranit: „Čím jasněji tyto znaky v scénické interpretaci vystoupí, tím lépe se na nich odrazí náš umělecký přístup k dílu." (WASSERBAUER 1957: 212) V této souvislosti Wasserbauer obzvláště zdůrazňuje nutnost „tvůrčího scénického přetaveni“ zmíněných znaků a zásadně odmítá doslova bezduchou scénickou ilustraci klasické hudebně-dramatické formy (s. 212). Hudba, tedy i hudba konkrétního díla z operní historie, určuje „nejen obsah scénického dění, ale svým komposičním stylem podstatně ovlivňuje i způsob jeho interpretování“ (s. 211). Na základě toho pak Wasserbauer vznáší požadavek respektování stylu při tvorbě operní inscenace, když styl chápe jako osobitou řeč tvưrce dané opery - „nese nejen znaky jeho individuálního uměleckého založení, ale i výrazné znaky historického údobí, v němž dílo vznikalo.“ (s. 212)

Problematiku realistické scénické interpretace díla v oblasti opery shrnuje Wasserbauer v kontextu problematiky formy, vztahu inscenace ke kompozičnímu stylu skladatele a právě onoho pojetí realizmu na (operní) scéně: „Závislost scénické interpretace na komposičním stylu interpretovaného operního díla nesmí být [...] nikdy pojímána jako pouhá záležitost vnější formy. Jde vždy o to, vyjádřit formu a styl hudebního dramatu tak, abychom cítili hlubokou organickou jednotu komposičního principu s jeho scénickou realisací, s jeho scénickým vyjádřením“ a dále „realistická scénická reprodukce vyzvedá svou tvorbou právě realistické složky operního díla, ale její reprodukční styl, jímž se tak děje, musí vycházet ze specifičnosti operního stylu.“ (WASSERBAUER 1957: 213)

V kontextu pojednání o problematice scénické interpretace opery se Wasserbauer vyjadřuje i k důležité, a i dnes velmi aktuální, otázce tvưrčí svobody a novátorství

9 Olga Janáčková v souvislosti se zdůrazněním Wasserbauerova respektu k operní formě konstatuje, že režisér „neužíval specificky činoherních postupů ani v případě vskutku realisticky cítěných operních předloh“ (JANÁČKOVÁ 1984: 505). To souviselo právě se skutečností, že si byl Wasserbauer dobře vědom speciálních požadavků v oblasti hudebně-dramatické interpretace, které klade operní partitura. 
v oblasti jevištní realizace operního díla. Zastává názor, že „volba scénické formy operní interpretace“ je sice záležitostí „tvưrčí svobody a uměleckým právem operního režiséra“, ale zároveň představuje velkou uměleckou zodpovědnost. Wasserbauer apelativně zdůrazňuje, že „svoboda nově a tvořivě realisovat operní dílo se však nesmí zvrhnout v uměleckou svévoli a schválnou originalitu. Takové umělecké ,novátorství je jen zdánlivě nové. Ve skutečnosti nepřispívá ničím kladným a novým k pravdivému osvětlení díla a jeho hlavní ideje." (WASSERBAUER 1957: 214) (10 $^{10}$

V tomto kontextu se Wasserbauer dostává až k formulování samotných pravidel interpretačního umění, do něhož samozřejmě zahrnuje i vlastní práci. Dle jeho názoru je pravá umělecká svoboda založena na schopnosti umělce (interpreta) sobě sama tuto svobodu dobrovolně omezovat - tím, že se bude snažit poctivě pronikat „k podstatě a zákonitosti díla“, že se bude upřímně snažit podřídit se jeho duchu a ideji, která - či spíše ono podřízení se - je základem interpretačního umění. Toto dobrovolné omezování sebe sama při interpretaci a jevištní realizaci operního díla, jak vyplývá z Wasserbauerových slov, je - paradoxně - velmi př́nosné a není třeba se mu bránit či se ho obávat: „Vždyt každé pravdivé hudebně-dramatické dílo nese v sobě celý svět citového a myšlenkového bohatství, že i když svou ideou a svým komposičním slohem, jímž ji hudebně realisuje, omezuje do jisté míry nespoutaný rozlet tvůrčí fantasie scénické interpretace, omezuje ji asi tak, jako břehy pevniny omezují oceán.“ (WASSERBAUER 1957: 214) Realistická interpretace (v celé šíri smyslu slova) tedy vychází z ideje díla. Právě realistickou interpretaci, ve smyslu pravdivou, skladatele (či autorů operního díla) respektující jevištní realisaci považoval Wasserbauer za správnou. Ctění autora hudebně-dramatického díla a stavění se do pozice reprodukčního umělce tento názor dokládá a vyjadřuje východisko Wasserbauerovy režijní práce. Právě ono často opakované charakterizování nejen Wasserbauerovy práce pomocí konceptu vycházení z partitury zcela vystihuje režisérův základní tvưrčí princip. Metoda Wasserbauerovy tvorby je reprezentována vycházením z partitury. Wasserbauer sám či prostřednictvím svých dirigentů - hudební partitury studoval a intenzivně v nich hledal to, co nebylo sděleno v textu. Ačkoliv šedesátá léta tedy dle některých badatelů (Janáčková, Toncrová ad.) přinesla posun od realistické interpretace k obohacení režijního pojetí o jevištní metaforu, nijak to zřejmě nepopřelo názor a postoj, který Wasserbauer zastával v letech padesátých, tedy i v době práce na článku „Princip realistické scénické interpretace v opeře“ z roku 1957. Jevištní metafora ho „pouze“ zavedla dále v jeho úsilí respektovat autora hudebně-dramatického díla a hledat a co nejvěrněji či nejsdělněji zprostředkovat jeho ústředni ideu.

Jak se tedy ideál jevištního realizmu projevoval ve Wasserbauerově tvorbě a myšlení o ní? Tendování k realizmu se ve Waserbauerově vedení herecké práce v kontextu doby muselo nutně vyrovnat s tehdejším způsobem aplikování tvưrčí metody K. S. Stanislavského. Odkazy na Stanislavského systém výchovy herce se pravidelně objevují jak v reflexích Wasserbauerovy operně-režijní tvorby, tak v jeho vlastních textech. V případě recenzí jde povětšinou spíše o zmínky či pasáže drobného rozsahu, které čtenáři nijak systematicky neozřejmují podstatu této metody a mnohdy ani nejsou prŕliš konkrétní,

10 Tento požadavek pravděpodobně plyne z reakce na tehdy - a v opeře vlastně i dnes - doznívající diskuze okolo „režisérismu“ na konci čtyřicátých a začátku padesátých let. 
co se týče tvůrčích postupů, jež jsou od Stanislavského přejímány. O něco obsáhleji a konkrétněji než recenzenti se o své tvưrčí metodě v souvislosti s postupy Stanislavského vyjadřuje Wasserbauer sám. Činí tak především v kontextu inscenací Mladé gardy (1951) a Tarasovy rodiny (1952), zejména když hovoří o pečlivém studiu pomocného a historického materiálu při práci na inscenaci atp. Lze souhlasit s názorem Dany Toncrové, která vysvětluje, že Wasserbauer prohlašoval za východisko své práce s hercem Stanislavského metodu, „[n]epochybně pod vlivem obecných tendencí zkreslených výkladů systému Stanislavského a jejich aplikace na činohru, operu, balet nebo loutkové divadlo." (TONCROVÁ 2000: 13)

\section{„Velká škola socialistického realizmu"11: Mladá garda a Tarasova rodina}

Pro reflexi Wasserbauerovy tvorby i teoretického uvažování o opeře jsou důležité dvě inscenace z padesátých let, jimž se v dobovém tisku dostalo značné pozornosti. Šlo o provedení Mladé gardy Julije Serhijovyče Mejtuse ${ }^{12}$ a Tarasovy rodiny Dmitrije Kabalevského ${ }^{13}$. Tyto soudobé novinky sovětské opery byly z dramaturgického hlediska výrazným politickým počinem. O tom ostatně vypovídá i době značně poplatná rétorika, která se objevuje v reflexích obou inscenací. I sám Wasserbauer se k inscenačním problémům těchto děl vyjádřil v tisku či programu k inscenaci (WASSERBAUER 1952). V těchto kritikách a názorech, byt zpravidla politicky angažovaných - a to hutně a i v delších pasážích - se lze dozvědět řadu důležitých informací v zásadě ze dvou okruhů. Jednak nám ukazují či potvrzují, čeho si cenila oficiální kulturní politika státu, a co tedy hledala v „příkladných“ inscenacích, za něž oba Wasserbauerovy počiny byly pokládány, jednak přinášejí - nutno říci pod nánosem ideologicky zabarveného diskurzu - cenný popis režijní metody, který je možné velmi dobře oddělit od politicky angažovaných stanovisek kritiků, a získat tak poměrně jasnou představu o podobě představení a režijním pojetí. Nutno dodat, že samotná Wasserbauerova reflexe (1952) rovněž obsahuje řadu ideologicky zabarvených floskulí, ale ty jsou velmi snadno, na první pohled, ${ }^{14}$ oddělitelné od věcných a skutečně sdělných pasáží, jež lze jednoduše ohraničit a jež ani dnešnímu čtenáři nijak nepřekáží v pochopení věcné stránky textu.

Tvůrčí metoda, kterou v obou případech zvolil inscenační tým, ve složení M. Wasserbauer (režie), František Jílek (dirigent), Miloš Tomek (výtvarník), byla vesměs jednoznačně vyhodnocena jako realistická. Z pohledu dobově ideologického mluvili kritici doslova o realizmu socialistickém. V této souvislosti je třeba zabývat se dvěma základními otázkami: Zaprvé, jaké politické, tj. oficiální režim podporující, hodnoty

11 Formulace z článku Miroslava Barvíky o inscenaci Tarasovy rodiny (BARVÍK 1952: 9).

12 Premiéra se konala 20. prosince 1951, dirigentem byl F. Jílek.

13 Premiéra se konala 29. listopadu 1952, dirigentem byl F. Júlek.

14 Jde většinou o ta nejznámější a nejfrekventovanější klišé - např. zdůrazňování př́itomnosti komunistů v inscenačním týmu, odkaz na ideovou konferenci, která přispěla k úspěšné práci, či explicitní vyjádření závazku inscenátorů, že se při shledání nějakého pochybení v práci napřššstě uchýlí k lepšímu plánování atd. 
byly v těchto inscenacích spatřovány? Zadruhé, co si pod pojmem socialistický realizmus v případě operní inscenační praxe kritici v té době představovali?

Předně, opakovaně je zdůrazňováno, že se jedná o sovětské novinky, které by měly jít příkladem soudobé československé operní tvorbě. Není sice opomíjeno hodnocení hudebních kvalit obou děl, zvláště pokud lze v partiturách nalézt prvky lidovosti (např. v podobě písně), ale hlavní pozornost je věnována libretům, respektive jejich námětům a způsobu zobrazování sovětského hrdiny. Mladá garda i Tarasova rodina se odehrávají za druhé světové války, resp. Velké vlastenecké války. V Mladé gardě je zpracováno počínání protifašisticky zaměřené skupiny mladých odbojářů, Tarasova rodina ukazuje osudy starého dělníka Tarasa a jeho rodiny na Ukrajině v době, kdy byla obsazena nacisty, až do jejich vyhnání Rudou armádou. Brněnská premiéra Mladé gardy dne 20. prosince 1951 byla vyzdvihována ${ }^{15}$ jako událost konající se v předvečer Stalinových dvaasedmdesátých narozenin, první uvedení Tarasovy rodiny 29. listopadu 1952 bylo př́íhodně provedeno v rámci tehdy již tradičního Měsíce československo-sovětského přátelství. ${ }^{16}$

Josef Burjanek hovořil o datu premiéry Mladé gardy jako o mezníku v historii české i slovenské opery, dokonce o jejím potenciálu vyvolat obrat v operní tvorbě, a o historickém významu jejího českého uvedení pro hudební vědu i kritiku (BURJANEK 1952a: 9). Ve svém textu pro Hudebni rozhledy vyjadřuje názor, že tato událost pomůže překonat předsudek o opeře jako o žánru neaktuálním. Prohlašuje, že

[n]ejenom z knihy, z filmu, z činoherní scény, ale i z operního jeviště bude se naše mládež napájet nadšením a vlastenectvím po př́íkladu krasnodonských komsomolců. A naši skladatelé, strženi příkladem sovětských, ujmou se těžkého, ale věru krásného a umělce důstojného úkolu postavit na operní jeviště zářící hrdinství našeho lidu v posledních letech [...]. [České provedení Mladé gardy] ukáže, jak je opera zvlášt uzpůsobena pro zobrazování heroismu socialistického člověka, aniž by se zříkala jediného z typických rysů svého žánru, své „opernosti“. (1952a: 9)

Nutno dodat, že tuto optimistickou prognózu Burjanek doprovází provoláním: „Nikdo jiný, než zase sovětští skladatelé, nemohl dokázat, jak marné byly pokusy buržoazního umění obrodit operu její degradací na nějakou zpívanou činohru." (1952a: 9) Autor této reflexe se k premiéře Mladé gardy vrátil ještě na konci roku 1952 (BURJANEK 1952b), tentokrát v rozsáhlejším textu, a to v mnohem vyváženějším ve smyslu umírněnějšího vyzdvihování politického významu ve prospěch věcné charakteristiky inscenace. Sice se ani v tomto článku nevyhnul pochvale zobrazování socialistického hrdiny či zmínění velkých zásluh inscenátorů, kterým se podařilo $\mathrm{v}$ divácích vzbudit nadšení a optimismus vystižením hlavní ideje díla či slovưm o příkladnosti stranické uvědomělosti jako důležitého činitele v procesu kvalitativního přerodu opery atp., ale je třeba konstatovat, že se vedle toho skutečně snažil vystihnout metodu práce na inscenaci a při tom nám poskytl cenné informace o podobě inscenace.

15 Viz např. (BURJANEK 1952a: 9).

16 Viz např. (BARVÍK 1952: 4). 
Wasserbauerův režijní styl, který poměrně rozsáhle a důkladně popisuje na straně 19, považuje za důsledně realistický, avšak vždy vycházející z hudby, tedy z partitury. Upozorňuje ale, že v závěru inscenace se režisér „uchýlil“ k symbolistickému zobrazení nesmrtelnosti mladogvardějců. Herci představující v tu chvíli již v popravě zastřelené muže fyzicky nepadnou na podlahu jeviště, ale zůstávají stát, jak doslova praví Burjanek, „stejně pevně a hrdě v novém, velkém světle, oslaveni hrdinsky znějící hudbou pod velkým vlajícím rudým praporem“ (BURJANEK 1952b: 19). Že „mladí hrdinové nepadli“ je kromě skutečnosti, že herci zůstali vzpřímeně stát, technicky zdůrazněno tím, že po salvě popravčí čety jeviště potemní, fašisté zmizí, a následně jsou ve světle ukázáni jen nepadnuvší hrdinové.

Burjanek označuje Wasserbauerovu režii za typicky operní, což vysvětluje právě již zmíněnou závislostí této složky na hudbě opery. Zmíněný realizmus v režii, jak lze tedy vyvodit z jeho slov, vychází z realizmu hudby. Jako pozitivní stránku Wasserbauerovy režie hereckého projevu vnímá úspornost v gestu i pohybu, oproštění od toporných schematických operních gest, soustředění hereckého výrazu spíše do „pravdivého, žitého pohledu“. Celkovou ukázněností ve výrazu se Wasserbauerově režii údajně podařilo zvýšit napětí v dramaticky nabitých situacích, přičemž bylo místy zapojeno náhlé velké gesto plné patosu - například zdvižená ruka zatatá v pěst. Dalším zřejmým úspěchem režijní práce byla schopnost udržet přehlednost i kontinuitu ve spletitém ději a gradaci scény po scéně „v dokonalém pochopení hlavních idejí díla“, což se dle Burjanka projevilo ve výsledku, který hodnotí jako „představení nebývalé čistoty a vzácně soustředěné k hlavním ideám díla“ (BURJANEK 1952b: 19). Netřeba reprodukovat slova o dalších složkách. Zmiňme pouze charakteristiku výpravy Miloše Tomka, v níž autor textu našel při vší realističnosti i plno poezie.

Burjankův článek je důležitý rovněž z hlediska skutečnosti, že jako celek vše výše zmíněné zasazuje do rámce, který činí z inscenace „příspěvek“ k socialisticky-realistickému stylu v oblasti inscenování opery. Z Burjankovy reflexe je patrné, co si kritik představoval pod pojmem socialistický realizmus v opeře, ač nás pasáže jeho textu soustředěné na toto téma přivádějí opět $\mathrm{k}$ několika ideologicky zabarveným floskulím. I přes to (či také právě proto) je možné Burjankovu představu o operní socialisticko-realistické tvůrčí metodě z textu pochopit. Kromě námětu, akcentace hlavní ideje díla a zpơsobu zobrazování socialistického hrdiny (tj. jakýmsi střídmým, realisticky pojatým, projevem herce přerušeným ve své umírněnosti na vhodném místě důrazným patetickým gestem) Burjanek - zcela v duchu Stanislavského terminologie - zdůrazňuje povahu procesu práce na inscenaci, když o ní hovoří jako studiu a školení. Je pozoruhodné, že se s takto explicitně pojmenovanou metodou přípravy inscenace setkáme i v jiných reflexích obou inscenací, zejména pak ve Wasserbauerově vlastním textu pojednávajícím o práci na Tarasově rodině, v němž se ovšem vrací i k Mladé gardě. Navíc, obvykle alespoň jednou v každé z takových dobových charakteristik procesu vzniku operní inscenace, obzvláště tedy zaměřených na dvě rozebírané sovětské opery, zazní jméno K. S. Stanislavského. Za pozornost stojí, že se tak však děje spíše ve formě samozřejmého odkazu a bez dalšího komentování podstaty této metody. Např́íklad v posledním odstavci již citovaného poměrně podrobného rozboru inscenace Mladé gardy Burjanek, po pochvale kolektivní 
práce a velkého a radostného úspěchu, ${ }^{17}$ volá po tom, ,aby nový způsob tvořivé práce a nový poměr $\mathrm{k}$ umění byl mnohem víc prohlouben až $\mathrm{k}$ bezpečnému ovládnutí tvůrčí methody K. S. Stanislavského.“ (BURJANEK 1952b: 20) Dále například v kontextu srovnání tří provedení Tarasovy rodiny, v Olomouci, Opavě a Brně, Miroslav Barvík konstatuje, že při přípravě inscenace došli v Opavě „ve studiu až tak daleko, že zavedli i v opeře nové studijní methody jednotlivých postav i scén, vedeni příkladem sovětských umělců a velkým vzorem Stanislavského.“ (BARVÍk 1952: 9) To považuje autor za další za zásadní klad uvedení Kabalevského opery u nás. Otázkou tedy zůstává, co pojem Stanislavského metoda v té době znamenal v operní inscenační praxi. Podrobněji se k ní vyjádřil právě Miloš Wasserbauer. Ke Stanislavskému odkazoval opakovaně a i v případě reflexe své práce na obou inscenacích sovětských oper v textu „Naše práce na ,Tarasově rodině‘ D. Kabalevského“ (WASSERBAUER 1952: 16).

V úvodních pasážích svého textu Wasserbauer hovoří o nových požadavcích na inscenační metodu, které kladou obě sovětské opery. Dle jeho názoru si aplikaci Stanislavského metody na operu vyžaduje již styl obou děl. Režisér upozorňuje, že se svým inscenačním týmem teprve pouze nastoupil „prvé kroky na cestě k pravdivosti a realizmu v interpretaci opery“ a že rozhodně nechce tvrdit, že si metodu již dokonale osvojili (WASSERBAUER 1952: 16). Využití Stanislavského metody při přípravě operní inscenace pro něho znamená především hluboké a důkladné studium „pomocného i historického materiálu“, vytvoření kolektivu, který jako celek prokazuje zájem na práci všech zúčastněných. Značná pozornost je věnována herci a novému způsobu práce s ním. Herec si má uvědomovat, že „vychází ze sebe, ze svého cítění hudebního i textového obsahu díla." V tom ho podporuje již zmíněné studium pomocného a historického materiálu, řada průběžně probíhajících diskuzí, které mají sloužit jako kontrola a korektiv jeho práce, jeho tvưrčí úsilí má směřovat k „pravdivému zobrazení skutečnosti ve vší její životní mnohotvárnosti“ (WASSERBAUER 1952: 16). Kromě studijní práce také údajně proběhly ideové konference $\mathrm{s}$ účastí dirigenta, režiséra a výtvarníka, přednášky, které měly pomoci ke správnému pochopení díla a metody práce při jeho nastudování. ${ }^{18}$ Inspiraci dle slov Wasserbauera souboru poskytly i sovětské filmy s tematikou Velké vlastenecké války a obsáhlá četba sovětských románů. Wasserbauerův text popisující vlastní práci na dvou tehdejších sovětských novinkách je příkladným referátem, zahrnujícím všechny nutné a době poplatné floskule charakterizující dobové pojetí Stanislavského systému.

Poněkud kuriózním, avšak při vědomí tehdejšího kulturně-politického tlaku spíše až frustrujícím dojmem působí příklady technických nároků, které na výtvarníka, režiséra a hlavně na technické pracovníky kladla partitura, a nutno podotknout s ní i př́sný požadavek důslednosti v realističnosti scény, svým předpisem scénických si-

17 Včetně pomyslné gratulace řadě umělců $\mathrm{k}$ nastoupení na cestu „k uvědomělému burcujícímu poslání umělce začínající nové epochy“ (BURJANEK 1952b: 20).

18 Dirigent František Jílek rozebral souboru dílo s pomocí různých ukázek, tehdejší rektor JAMU, Ludvík Kundera, pronesl přednášku o „socialistickém realizmu a kosmopolitismu v hudbě a operní reprodukci“. Do příprav se zapojil i Josef Burjanek přednáškou o „nových cestách opery od Mejtusovy ,Mladé gardy“ ke Kabalevského ,Tarasově rodině““ - včetně výkladu o jejich kulturně-politickém významu atd. 
tuací typu požár školy, nálet sovětských letadel na město či příjezd tanku obsazeného lidmi (WASSERBAUER 1952: 16).

Zřejmě nejvíce prostoru bylo Kabalevského Tarasově rodině věnováno v článku Miroslava Barvíka s názvem „Učme se ze sovětského vzoru“ (BARVÍK 1952: 4-10). Ve svém srovnání tří inscenací Tarasovy rodiny (v Brně, Olomouci a Opavě) hodnotí nejlépe provedení brněnské. Barvík opakovaně uvádí, že se jedná o nejlepší soudobou sovětskou operu. I proto má sloužit jako vzor, který lze zároveň dle jeho názoru označovat a vnímat jako školu socialistického realizmu, což s sebou přineslo hlubší zájem našich umělců o problematiku umělecké reprodukce (BARVÍK 1952: 8- 9). Barvík se bohužel věnuje více opeře samotné než analýze jejího československého provedení na jevišti.

\section{Požadavky na novou československou operu vzešlé ze dvou „sovětských vzorů”}

V rámci kulturně-politického hodnocení významu uvedení dvou sovětských operních novinek u nás se autoři dobových reflexí vyjádřili také ke stavu a potřebám soudobé československé operní tvorby. Josef Burjanek (1952a: 9) v kontextu vzniku inscenace Mladé gardy vytýká našim skladatelům, že se vyhýbají aktuální tematice, která by reflektovala poslední léta. Nabádá je, aby se právě po vzoru „tak krásných sovětských oper“ (BURJANEK 1952a: 9) uchylovali k námětům, jako jsou např.: „odboj našeho lidu vedený Komunistickou stranou s pomocí Rudé armády proti fašistům“, „hrdinstvím a optimismem svítící život a boj Julia Fučíka“, „znárodnění průmyslu“, „cesta k zemědělským družstvům“, „marné teroristické akce zahraničních agentů proti představitelům lidové správy“, „boj o rudé hvězdy nad ostravskými šachtami“ či „růst našich staveb socialismu a s ním socialistických lidí“ (BURJANEK 1952a: 9). Miroslav Barvík konstatuje, že od roku 1945 (do roku 1952) bylo u nás napsáno zhruba čtyřicet nových oper, avšak žádná nedosahuje takových kvalit, aby mohla být postavena do „slavné smetanovské linie českých oper“. „Sovětské vzory“ mají tedy posloužit jako inspirace a napomoci situaci vylepšit, protože „vlivy formalismu a kosmopolitismu způsob[i]ly hodně škod jak v názoru na operu vůbec, tak i ve způsobu jejího vytváření (od tvůrčího procesu skladatelského až po inscenaci a hudební nastudování).“ (BARVÍK 1952: 5) Uvedení obou sovětských oper proto Barvík rovněž vnímá jako historický mezník. Inspirace v „sovětském vzoru“ by se dle jeho názoru, vyjádřeném na samém konci článku věnovanému třem inscenacím Tarasovy rodiny, měla projevit ve vytvoření nové české a slovenské národní hudby socialistické epochy (BARVÍK 1952: 10).

Z odkazů na Stanislavského a stručných popisů konkrétních postupů, které z jeho systému přebíral, lze Wasserbauerův postoj k této koncepci tvorby charakterizovat jako vědomě inspirovaný a selektivně přijímaný vliv na vlastní režijní práci. Ostatně Wasserbauer opakovaně vyjadřoval nevưli vưči mechanickému či direktivně důslednému aplikování této (či snad jakékoliv) metody na vlastní práci, bez promýšlení a připouštění hledání nových postupů. Není proto zřejmě tak zásadní ptát se, jak dobře byl Wasserbauer seznámen se Stanislavského pojetím herecký tvorby. Důležité je především to, co 
si pod pojmem „Stanislavského metoda“ představoval, tj. co proklamativně považoval za metody své vlastní tvorby a čím z toho se řídil. V kontextu př́istupu Stanislavského tvorby pak je třeba pouze rozpoznat konkrétní styčné body Wasserbauerovy práce s jeho ruským „vzorem“.

Dana Toncrová identifikovala některé aspekty, v nichž se Wasserbauer inspiroval u Stanislavského (TONCROVÁ 2000), respektive u onoho dobového zkresleného pojetí této metody u nás. Předně šlo o onu pravdivost v oblasti zobrazení umělecké skutečnosti, jíž byla charakterizována tehdejší realistická interpretace operního díla na scéně, dále „služba“ režiséra autorovi, hledání a zprostředkování ústřední ideje díla, související s oním „proč“ autor dílo psal, jak Wasserbauer často uvádí, ${ }^{19}$ či - jak to formuluje Toncrová - „pojetí herce jako ústředního nositele významových kvalit díla“ (TONCROVÁ 2000: 14). K těmto postupům samozřjejmě patří i pečlivá příprava členů inscenačního týmu včetně herců, pojatá jako důkladné studium doprovodného a historického materiálu, kladení důrazu na kolektivní práci, včetně jejího vzájemně inspirativního a korektivního potenciálu atd.

\section{Realistická tvůrčí metoda v režiích Miloše Wasserbauera}

Od socialistického realizmu, jímž byly charakterizovány dvě inscenace sovětských oper z počátku padesátých let, pokračoval Miloš Wasserbauer cestou realizmu k dalším pozoruhodným počinům své režijní tvorby. Josef Burjanek (BURJANEK 1970: 5) se v nekrologu nazvaném „Za Milošem Wasserbauerem (1907-1970)“ pokusil ozřejmit Wasserbauerovu cestu k realistické tvůrčí metodě a snažil se také charakterizovat jeho režijní styl. Konstatuje, že příchod socialismu přišel Wasserbauerovi logický a že „k inscenačnímu realizmu nedocházel pod ideologickým tlakem“, nýbrž k němu sám tíhnul bez politické motivace. Výraz „realistický“ volí sice pro celkové, shrnující označení jeho režijního stylu, avšak vnímá ho poněkud šířeji jako „umělecky transformované a metaforizované jevištní zobrazování lidských osudů a akcentuace myšlenek, vyvolávajících osobní i sociální dramata, převraty a katarze, s tím ovšem, že k podstatě jeho koncepce i realizace patří snaha po čitelnosti pro danou společenskou etapu a její konkrétní publikum.“ (BURJANEK 1970: 6)

Právě v souvislosti s inscenacemi dvou sovětských oper charakterizuje Olga Janáčková Wasserbauerovu režii v padesátých letech jako stylově založenou na dominanci zúženého realistického cítění, „z něhož režisér jen občas vybočil k vyšší stylizaci výrazových prostředků zejména v závěrečných jednáních oper“ (JANÁČKOVÁ 1984: 504). Jako příklad takového stylového vybočeni uvádí Janáčková použití „jisté podoby živého obrazu“, jak tomu bylo např. v Cikkerově Juro Jánošikovi (1954), Smetanově Daliborovi (1957) či ještě i v inscenaci Janáčkovy Věci Makropulos z počátku šedesátých let (1962). Dle Janáčkové se teprve

19 Právě v tomto aspektu se, jak upozorňuje Toncrová (2000: 14), projevilo značné zjednodušení Stanislavského myšlenek. 
postupem času [...] z těchto stylových vybočení vyvinuly skutečné jevištní metafory. V šedesátých letech začal realizmus v jeho tvorbě pozbývat zúženého významu a byl jím chápán jako realizmus stále více obohacovaný řečí divadelních metafor. Tímto modifikovaným realizmem, závislým na různých historických stádiích vývoje operní formy, nazíral Wasserbauer kterékoliv operní dílo. Výrazné napětí mezi historizujícím a aktualizujícím pohledem bylo jedním ze základních rysů Wasserbauerových inscenací, na míře vyváženosti obou aspektů závisela do značné míry konečná podoba každého interpretovaného díla. (JANÁČKOVÁ 1984: 504)

\section{Scénický realizmus Waltera Felsensteina jako inspirační zdroj?}

Dana Toncrová, když se snaží identifikovat inspirační zdroje Miloše Wasserbauera, upozorňuje na skutečnost, že se režisér ve své tvorbě po druhé světové válce v mnoha ohledech názorově shodoval s programem hudebního divadla Waltera Felsensteina, intendanta německé Komické opery ${ }^{20}$ (TONCROVÁ 2000: 14). Částečná podobnost tvůrčích názorů a východisek tvorby zřejmě nejlépe charakterizuje vztah Wasserbauera k německému režisérovi, jehož scénické pojetí opery platilo v té době za směrodatné v oblasti inscenační praxe. Dle našeho názoru totiž nelze říci, že by se Wasserbauer Felsensteinovou tvorbou přímo a nějak zásadně inspiroval, spíše na ni - v praxi či v teoretické reflexi operní tvorby - reagoval. Rozhodně nešlo o nadšené následování jeho režijních postupů či snahu vyrovnat se jejich povaze či úrovni. ${ }^{21}$

Jaké tedy byly podobnosti a odlišnosti scénického pojetí opery těchto režisérů, když oba vycházeli z realizmu a považovali jej za svůj tvưrčí názor? Dana Toncrová opakovaně upozorňuje na skutečnost, že Wasserbauerovy režie, stejně jako ty Felsensteinovy, vycházely z partitury (TONCROVÁ 2000). Olga Janáčková zmiňuje Felsensteinovu práci v souvislosti s Wasserbauerovou inscenací Lišky Bystroušky z roku 1965. Wasserbauerovu Bystroušku označuje za osobitou polemiku „s někdejší Felsensteinovou ortodoxně realistickou interpretací tohoto díla“ (JANÁČKOVÁ 1984: 506). Janáčková vyzdvihuje filozofické vyznění inscenace, která - připomeňme - do centra dění postavila Revírníka a perspektivu pouti nekonečnou lidskou a zviŕrecí existencí, vykládané Janáčkovou jako filozofické zamyšlení nad smyslem života (JANÁČKOVÁ 1984: 506).

Miloš Wasserbauer sám se rok před svojí inscenací Bystroušky, kterou se otevírala nová budova Janáčkova divadla, vyjadřuje v rozhovoru s Rudolfem Pečmanem o svém pohledu na Felsensteinovu práci. Vysoce vyzdvihuje jeho zásluhy v oblasti zdivadelnění opery a prohlašuje, že v tomto ohledu jde s ním stejnou cestou a že považuje „herce a jeho pravdivé herectví za podstatu operní interpretace“ (PEČMAN 1964: 186). Odlišnosti své práce od té Felsensteinovy vidí především ve dvou oblastech. Zaprvé v chápání realizmu ve výtvarné stránce inscenace. Wasserbauer zastává, a sám ve své tvorbě uplatňuje, názor, že v oblasti scénografie lze „dosáhnout realisticky pravdivého účinku na diváka moderními, scénicky výtvarnými prostředky [...].“ Implicitně se tímto tvrzením

20 Miloš Wasserbauer (nar. 1907) byl pouze o šest let mladší než Walter Felsenstein.

21 Na tento Wasserbauerův postoj upozornila autorku této studie E. Dufková v rozhovoru ze dne 16. března 2016. Jeho audio záznam je uložen v soukromém archivu autorky (HAVLÍčKOVÁ KYSOVÁ 2016). 
vymezuje proti značné míře popisnosti realizmu výtvarné složky Felsensteinových inscenací, což lze vyvodit i z jeho vymezení se vůči realizmu v hereckém projevu, jež uplatňuje německý režisér. Tedy zadruhé Wasserbauer poukazuje na odlišnost svého režijního pojetí herecké tvorby a formy uplatnění realizmu v této oblasti. Tvrdí, že na rozdíl od Felsensteina nepoužívá ,jednu jedinou (tj. realistickou) formu jevištního projevu herce k interpretaci oper různých kompozičních slohů. Skladatelský sloh a jeho specifičnost mne jako režiséra inspiruje k pokusu nalézat novou odlišnou formu hereckého projevu, kterou by určoval právě ten či onen kompoziční sloh.“ (PEČMAN 1964: 186) Dodává k tomu však zásadní poznámku, když vyjadřuje svoje přesvědčení, že i při korespondenci formy hereckého projevu se specifičností konkrétního kompozičního stylu „vždy psychologie a charakter postav, jejich vzájemné vztahy, jednání a cítění na scéně budou mít realistický základ a obsah, budou mít pravdivost životní.“ (PEČMAN 1964: 186)

\section{Herec v centru zájmu}

„Nezapomínám, že operní herec se vyjadřuje zpěvem.“ Miloš Wasserbauer in [PEČMAN 1964: 186]

Kromě partitury Miloš Wasserbauer přikládal v rámci formování inscenace zcela zásadní význam herci, respektive herectví. ${ }^{22}$ Povšimněme si, že se v kontextu Wasserbauerovy tvorby často mluví o herci, nikoliv (primárně) o pěvci. Dle Olgy Janáčkové byl hercův výkon dokonce vedoucí složkou každé Wasserbauerovy inscenace, podobně jako tomu bylo v jevištním díle F. Pujmana. Stylovým východiskem při práci s hercem se dle Janáčkové stal Wasserbauerovi realizmus (JANÁČKOVÁ 1984: 504). Janáčková také uvádí, že režisér věnoval zvláštní pozornost zpívajicimu herci a jeho výrazové kultuře:

Vedl herce vzásadě v duchu psychologického realizmu, uzpůsobeného ovšem specifickým slohovým vlastnostem inscenované opery. Nepřipoutával ho meloplasticky k hudbě, nebot si přál, aby jeho výkon souzněl s celkovou podobou hudebního dramatu, již kontrapunkticky doplňoval, zvýrazňoval a svébytně organizoval. Hercův motorický projev byl dokonce v režisérových inscenacích mnohdy záměrně traktován v jiném rytmu než hudba. (JANÁČKOVÁ 1984: 505)

Jak plyne z řady jeho výroků, Wasserbauer věnoval problematice operního herectví značnou pozornost ve své divadelní práci i ve svých úvahách. Povšimněme si, že Wasserbauer hovoří o operním pěvci povětšinou jako o „herci“. Byl si plně vědom rozdílu mezi činohercem a hercem operním. Na jedné straně usiloval o to, aby operní inscenaci nedominoval pouze co nejdokonalejší zpěv, at’ už z hlediska techniky či i po stránce výrazové, ale aby si pěvec osvojil a na jevišti vykazoval také herecké dovednosti. Na straně druhé si však velmi dobře uvědomoval specifičnost hereckého projevu v opeře, tedy vnímal celou řadu požadavků v oblasti hudební, které s sebou nese opera, byt ji

22 Dle slov E. Dufkové (v rozhovoru s autorkou této studie z 3. března 2016) Wasserbauer „ctil herce“. 
vnímáme jakožto žánr divadelní (ač samozřejmě ne jen divadelní). Zpěvní projev či „zhudebněná řeč“, jak o nich Wasserbauer hovoří, má dle jeho názoru svůj rozmanitý styl, který plyne z celkového kompozičního stylu opery dané doby. Wasserbauer to dokládá na příkladu Verdiho árie, která dle jeho názoru „musí zůstat árií, tj. zpěvem. Velká zpěvní kantiléna, typická pro jeho sloh, nesmí utrpět na své vznosnosti hereckým výrazem, nesmí se roztrhat, rozdrobit.“ (PEČMAN 1964: 186) Proto by měl operní herec „nalézt syntézu kantabilnosti a pravdivého realistického výrazu obsahu zpívaného slova“ (PEČMAN 1964: 186). Režisér si však plně uvědomuje obtížnost hledání takové syntézy a nároky, které v tomto ohledu klade nová i starší opera.

Za zcela zásadní, ovšem opět částečně problematickou složku považuje pohyb, o němž přirozeně uvažuje v souvislosti se zpěvem a herectvím. Jako problém vnímá míru „pohybového, zpěvního a dramatického výrazu herce“, protože dle jeho názoru není možné, aby se například „postavy mozartovské projevovaly tak realistickou formou scénickou jako postavy Janáčkovy nebo postavy oper veristických.“" (PEČMAN 1964: 186) Tento názor opět doprovází svým obligátním tvrzením, že „[m]íra realizmu a stylizace jevištního projevu je určována hudebním slohem“ (PEČMAN 1964: 186).

\section{Problematika soudobé opery}

Názory Miloše Wasserbauera na soudobou operní tvorbu lze rovněž nacházet v řadě textů, v nichž se vyjadřoval ke konkrétní inscenaci (většinou v programu) nebo obecněji k vlastní tvorbě. Problémy, s nimiž se dle jeho názoru soudobá opera potýká, charakterizoval také v rozhovoru s Rudolfem Pečmanem pro časopis Hudebni rozhledy (PEČMAN 1964). Své názory Wasserbauer vyslovuje skromně, zřejmě s pomyslným přenecháním této problematiky kompetenci svých kolegů, zejména dirigentům. Jeho hodnocení soudobé operně-skladatelské praxe se tedy zaměřuje především na kvality, které jsou podstatné pro úspěch divadelní inscenace. Wasserbauer se tak přirozeně k problematice vyjadřuje z pozice operního režiséra.

Wasserbauer zastává názor, že operu je možné hodnotit až po jejím provedení, nikoliv pouze z partitury. Jako obzvláště problematickou vnímá skutečnost, že skladatelé mnohdy lpějí na staré konvenční formě deklamační opery a scénické představy o vlastním díle zakládají na již vyzkoušených scénických postupech. Wasserbauer upozorňuje na skutečnost, že ne každý skladatel, byt úspěšný v jiném hudebním žánru, je schopen napsat dobrou, tj. po dramatické stránce funkční, operu (PEČMAN 1964: 185). Vyžaduje po skladateli, aby měl divadelní cítění či aby si uvědomoval skutečnost, že tvoří dílo určené pro divadlo: „Skladatel by měl v opeře komponovat především dramatické situace scénicky nově viděné a účinně vyhrocené. Měl by [...] vycitovat scénické dění a stát se při komponování hudebním divadelníkem. Měl by respektovat specifické zákony scénického umění, které at’ se mění ve své formulaci s novou estetikou operní [...] jak chtějí, musí být směrodatnými v prvé řadě pro operního skladatele." (PEČMAN 1964: 185)

V českém prostředí vnímá Wasserbauer jako vzor správného přístupu či možné inspirativní východisko z výše zmíněných problémů tvorbu Leoše Janáčka. O Janáčkovi 
hovoří jako o mistrovi opery, jenž byl schopen ve své tvorbě ztvárnit skutečnost, která nás obklopuje. Wasserbauer odkazuje konkrétně na Janáčkovo vycházení z dobových „nápěvků hovorové řeči“, jež byl schopen přetvořit ve „vysoce stylizovaný a hudebně samostatný útvar“ (PEČMAN 1964: 185). V této souvislosti hovoří Wasserbauer o problémech, kterým se - ač to samožrejmě neplatilo obecně - dle jeho povědomí věnují na Západě, totiž technickým a kompozičním prostředkům a exkluzivní formě opery. Technické prostředky jsou však dle Wasserbauera oprávněné, jen pokud zesilují scénickou účinnost a navozují atmosféru. Hudba by však dle jeho názoru měla vyjádřit vše sama svojí podstatou (PEČMAN 1964: 185).

\section{Režijní problémy interpretace oper Leoše Janáčka}

V šedesátých letech 20. století se režijní tvorba Miloše Wasserbauera začala pozvolna odklánět od ideálu realistické interpretace. V jeho stylu se více začalo projevovat tendování k jevištní metafoře. Tato skutečnost se projevila i v jeho uvažování o operní režii. Značnou mírou ji jistě podněcovalo i inscenování oper Leoše Janáčka.

V kontextu janáčkovské inscenační tradice je režijní dílo Miloše Wasserbauera považováno za jedno z těch formativních. Opery Leoše Janáčka tvoří zvláštní kapitolu Wasserbauerovy profesní kariéry a ostatně i brněnské operně inscenační historie. O zpracování této tematiky se pokoušela již řada badatelo̊. Například Jindřiška Bártová a Monika Holá věnovaly této problematice asi pětadvacetistránkovou kapitolu ve své knize Režijni přistupy k operám Leoše Janáčka v Brně (BÁRTOVÁ a HOLÁ 2004: 81-124), Dana Toncrová se podrobně - pod vedením Bořivoje Srby - věnovala inscenaci $Z$ mrtvého domu nejprve ve své seminární práci (TONCROVÁ 1999), následně v jedné kapitole své diplomové práce, v níž kromě této inscenace zpracovala i Př́hody lišky Bystroušky z roku 1965 (TONCROVÁ 2000), a pak ještě ve studii publikované ve Sborníku praci Filozofické fakulty brněnské univerzity (TONCROVÁ 2002). Zejména scénografické stránce Wasserbauerových janáčkovských inscenací se věnovala Jiřina Telcová (např. TELCOVÁ 1965 a 1966), Jiří Hilmera pak zpracoval společné inscenace, tj. včetně řady těch janáčkovských, M. Wasserbauera a Františka Tröstera, atd.

Právě inscenace $Z$ mrtvého domu z roku $1958^{23}$ je zpravidla považována za Wasserbauerův nejúspěšnější janáčkovský scénický počin. Svědčí o tom i skutečnost, že na základě hostování s touto inscenací na podzim roku 1963 v Perugii, kde ji zhlédl tehdejší ředitel La Scaly, dostal Miloš Wasserbauer pozvání k pohostinské režii v milánské La Scale ${ }^{24}$ (POLEDŇÁKOVÁ 1965: 5). V roce 1968 došlo dokonce k obnovení premiéry této inscenace. Premiéra Příhod lišky Bystroušky z roku 1965 pak znamenala mezník v historii brněnského divadla, když jí byla otevřena nová budova Janáčkova divadla.

23 Premiéra se konala 26. června 1958. Wasserbauer na inscenaci spolupracoval s dirigentem Františkem Jílkem a výtvarníkem Františkem Trösterem.

24 Režíroval tam, opět ve výtvarné spolupráci (scéna i kostýmy) s Františkem Trösterem, Šostakovičovu Katěrinu Izmajlovu. 
Pokusíme se tedy charakterizovat režijní přístup Miloše Wasserbauera k operám Leoše Janáčka a uvažování o něm. Činíme tak na základě analýzy dostupných archivních materiálů a ohlasů v tisku, přičemž středem zájmu jsou opět Wasserbauerovy myšlenky, které zveřejnil, a jeho vlastní explikace této problematiky. V této souvislosti si rovněž klademe otázku, zda či do jaké míry lze jeho režie Janáčkových oper charakterizovat ve smyslu slov, která ve svém monografickém hesle použila Olga Janáčková, když hovořila o „inspirovaném“ či „subjektivním“ realizmu obohaceném „metaforickým zpo̊sobem vyjadřování“, který „často užíval výtvarného výraziva“ (JANÁČKOVÁ 1984: 505). Janáčková totiž tuto charakteristiku podporuje - vedle odkazu na roztrženou chrámovou oponu na počátku Verdiho Otella z roku 1967 - právě příklady z janáčkovských inscenací, konkrétně režijním využitím visutého chodníku ve druhém plánu Trösterovy scény k Jeji pastorkyni z roku 1961 a podobným příkladem z Přihod lišky Bystroušky z roku 1965 (JANÁČKOVÁ 1984: 505).

Wasserbauer nazývá Janáčkův kompoziční styl realistickým - ,je velmi blízký scénické realistické methodě interpretační ve smyslu činoherním“. V tomto kontextu Wasserbauer hovoří také o skutečnosti, že jistá „vystupňovanost“ realizmu zavedla řadu inscenátorů na scestí naturalismu (WASSERBAUER 1957: 213). V souvislosti s označením Janáčkova kompozičního stylu jako realistického však Wasserbauer upozorňuje, že se v jeho dílech objevují i formálně ucelené operní útvary:

Na př. v jeho Pastorkyni překrásný ensemble v prvém dějství. Není to ovšem pouhý Janáčkův ústupek konvenční operní formě. Volil-li tak výbušný člověk, jako byl Janáček, dramatik, vyjadřující se hutnou uměleckou zkratkou, ke svému hudebnímu vyjádření lidové moudrosti („Každý párek si musí svoje trápení přestát“) starou formu ensemblu, věděl proč tak činí. U Janáčka není myslitelné, aby pojal tento ensemble jako pouhé hudební zastavení v dramatickém dění. Chtěl jím vyzvednout nějakou závažnou myšlenku, upoutat na ni pozornost posluchače, chtěl tím zdánlivým dějovým zastavením zdůraznit její důležitost. Janáček tímto hudebně překrásným ensemblem geniálně - hned v exposici díla - vyjádřil a vlastně už anticipoval celý dramatický vývoj vzájemného vztahu dvou hlavních postav opery, Jenůfky a Laca, i když zdánlivě jen podružný moment v dramatickém ději, a to ještě ve vztahu Jenůfky a Števy. Scénická interpretace zde musí navodit atmosféru velké závažnosti, aby si ji posluchač maně připomínal ještě na konci, před slavným závěrem opery. Zde už nevystačíme činoherními prostředky inscenačními, nebot zde Janáčkův realizmus použil uměleckých prostředků specificky operních, a přece starou formu operní naplnil novým smyslem a dal jí novou funkci. (WASSERBAUER 1957: 213)

Každou z oper Leoše Janáčka považuje Wasserbauer za svět pro sebe, který si žádá zvláštní a jedinečný inscenační přístup. Navíc dle jeho názoru „celé Janáčkovo operní dílo tvoří nedílný umělecký celek, jímž Janáček vyslovuje své umělecké a filozofické krédo, pokaždé jiným způsobem a v jiných obměnách.“ (PEČMAN 1964: 186) Za hlavní problém inscenování považuje Wasserbauer „vztah mezi logikou psychologické základny Janáčkova operního díla a mezi u m ě l e c k o u [zvýrazněno v originále, poznámka ŠHK] logikou jejího scénického vyjádření.“ (PEČMAN 1964: 186) Inscenovat Janáčkovu 
operu moderně znamená najít vhodnou „scénickou syntézu janáčkovského ,psychologického realizmu' a moderních výrazových prostředků, jimiž Janáček vyjadřuje obsah svých děl.“ (PEČMAN 1964: 186) Pět let před rozhovorem s Rudolfem Pečmanem tento postoj Wasserbauer formuloval v časopise Slovenské divadlo zevrubněji. Zdůrazňoval nutnost vytvořit účinnou scénickou atmosféru, v níž by se Janáčkovy postavy mohly přirozeně a pravdivě vyvíjet. Toho je dle režiséra možné dosáhnout pouze volbou vhodných prostředků v oblasti jevištní interpretace opery, která musí vyplývat z oné syntézy ideového a psychologického obsahu Janáčkovy hudby a osobitosti i novosti formálních prostředků skladatele (WASSERBAUER 1959: 135).

Wasserbauer dále zdůrazňuje nutnost klást důraz na humanistickou ideu Janáčkova díla, avšak zároveň upozorňuje, že pochopit a „interpretačně respektovat p o d s t a t u [zvýrazněno v originále] Janáčkovy hudby“ může být velmi obtížné. Podstatu operního realizmu jeho děl spatřuje režisér - ač to lze klasifikovat jako významové klišé - v jejich ideovosti, v pravdivosti citu a lidských vztahů, které mají tato díla zobrazovat na scéně (PEČMAN 1964: 186). Wasserbauer považuje za zcela zásadní podrobovat Janáčkova díla - před jejich inscenováním - důkladnému psychologickému rozboru.

Wasserbauer se často zabývá otázkou ideovosti (nejen) Janáčkova díla v souvislosti s problémy interpretace ideovosti skladatelova díla, které byly dle režisérova názoru zbytečně dlouho opomíjeny. Rudolf Pečman ho proto v jejich společném rozhovoru vyzval, aby tuto problematiku více objasnil (PEČMAN 1964: 186). Wasserbauer se nejprve k této otázce vyjadřuje poněkud vágně či až příliš obecně, když konstatuje, že je třeba Janáčkovo dílo očistit od „zjednodušujících, vulgarizujících interpretačních výkladů“, že režisér musí být především dramaturgem Janáčkova díla, že „[s]cénické zvýraznění idey díla se musí dít prostředky opravdu básnivými [...] i čistě divadelně účinnými“, aniž by $\mathrm{k}$ tomu byl použit pouze „prázdný divadelní efekt“ mnohdy pouze zakrývající „nemohoucnost interpretů“. Konkrétněji v rozhovoru s Pečmanem Wasserbauer ožrejmuje pouze ono využití básnivých prostředků, k němuž dle jeho názoru nabádají „typicky janáčkovské katarze jeho oper“, přičemž poukazuje na specifické závěry oper L. Janáčka. Více je ovšem v rozhovoru necharakterizuje. Učinil tak však již zhruba o pět let dříve ve svém textu pro časopis Slovenské divadlo, v němž v souvislosti s akcentací ideje díla uvádí jako příklad dle jeho názoru nesprávné interpretace Výletů pana Broučka. Wasserbauer upozorňuje, že se tato opera bohužel mnohdy stále ještě pojímá jako komická opera běžného typu, zatímco ji takto nechápal ani sám Janáček. Inscenace Výletů pana Broučka nesmí vyznít jako úsměvné, shovívavé chápání lidských slabostí a hlouposti, měla by pak podtrhnout sarkastické odsouzení malosti a podlé zbabělosti měštáka. Pokud se tak nestane a inscenátoři zvolí jiný, respektive „běžný“ komický výklad, dostanou se do rozporu s ideou obsaženou již v Janáčkově hudbě. Tento rozpor bude velmi patrný a způsobí, že se hudba bude jevit diváku „nezmysel’ne dizonantná, drsná, ostrá a bičujúca“ (WASSERBAUER 1959: 138).

Dalším pozoruhodným příkladem nesprávné jevištní interpretace Janáčkovy opery je dle Wasserbauera případ, kdy se režisér nechá zmýlit a nepovšimne si, že nositelem ideje je epizodní postava, jak je tomu dle jeho slov například v Osudu či ve Věci Makropulos. V Janáčkových operách se totiž setkáváme s tím, že „svojou hudbou ideovo umocňuje opernů postavu, ktorá nie je libretom počas razvíjania deja zdôraznená“ (WASSERBAUER 1959: 
138). Jak Wasserbauer ukazuje na př́ikladu Kristýnky ve Věci Makropulos, je tedy na režisérovi, aby takovou epizodní postavu od začátku zdůraznil nějakými výrazovými prostředky a po celou dobu představení ji takto zvýrazněnou vedl až do konce. Pouze takto pojatá a akcentovaná postava bude $\mathrm{v}$,janáčkovském závěru“ opery náležitě připravená a podpoří - logicky a přirozeně - vyznění ideje Janáčkova díla (WASSERBAUER 1959: 138).

V rozhovoru s Rudolfem Pečmanem režisér také vyslovuje mínění, že z hlediska interpretace musejí ony specifické janáčkovské závěry opery na scéně „vyrůstat především z hudby“ a že by měly být apoteózou čisté ideje díla, přičemž shrnuje svá tvrzení slovy o tom, že považuje Janáčkovy opery za v zásadě optimistické (hovoří doslova o jejich optimistickém „charakteru“) (PEČMAN 1964: 186). Rudolf Pečman se však s tímto vyjádřením nespokojuje a vybízí režiséra, aby tento názor ještě více objasnil, protože (nejen) tehdejší chápání Janáčkových oper se obecně přiklánělo k názoru, že jde o díla spíše tragická. Navíc, jejich dramatičnost je často dle Pečmanových slov stavěna do protikladu k operám Smetanovým.

Schematismus tohoto pojetí Wasserbauer zásadně odmítá. Tragično Janáčkových oper je dle jeho názoru prodchnuto "Janáčkovou kladnou vírou v život, v člověka“, v lidské hodnoty a touhy „po lepším, svobodnějším životě“ (PEČMAN 1964: 187). Tyto rysy v různých obměnách - at̉ už šlo o dobové floskule či nikoliv - nachází Wasserbauer v každé z Janáčkových oper, a proto hovoří v případě závěrů jeho operních děl o katarzích a připisuje jim hymnické kvality. Výstižně upozorňuje, že humanistické ideje jsou $\mathrm{v}$ Janáčkově díle, respektive $\mathrm{v}$ jeho hudbě, vyjadřovány specifickým typem zkratky a náznaku. Tuto specifickou hudební mluvu je dle Wasserbauera třeba „scénicky umocnit, dramatizovat, básnicky ji naplno doslovit“ (PEČMAN 1964: 187).

V souvislosti s Janáčkovou tvorbou se Wasserbauer pozastavuje nad nesprávným chápáním tzv. „typického janáčkovského opakování“, k němuž v době vzniku jeho děl obvykle docházelo (WASSERBAUER 1957: 213). Tento specifický vyjadřovací prostředek skladatele chápe Wasserbauer jako př́klad podnětu k „tvưrčímu interpretačnímu postupu v oblasti rozkrývání psychologických hlubin janáčkovské vokální melodie“, který mají inscenátoři k dispozici (WASSERBAUER 1957: 213). Tímto př́́kladem podporuje režisér svůj názor, že i realistický skladatelský styl je či může být stále stylem operním, přičemž upozorňuje, že si „[r]ealistická reprodukce ve smyslu činoherním neví [...] s takovými místy Janáčkova stylu rady a řeší je scénicky konvenčně - t. j. nezasazuje je jako tvárný prvek do celkového scénického dění." (WASSERBAUER 1957: 213) Wasserbauer tedy spatřuje v onom „typickém opakování“ nejen charakteristický prvek Janáčkova hudebního stylu, nýbrž - především - prostředek, který poskytuje řadu možností v oblasti psychologického zdůvodnění scénického dění (WASSERBAUER 1957: 213).

\section{Wasserbauerův režijní přístup k inscenaci Z mrtvého domu (1958)}

Inscenace poslední opery Leoše Janáčka, $Z$ mrtvého domu, kterou Wasserbauer režíroval na konci padesátých let (1958), byla velkým úspěchem. Vzhledem ke skutečnosti, že byl především na základě této práce Wasserbauer pozván k pohostinské režii v milánské La Scale, 
lze ji vnímat jako jeden ze zásadních počinů v celé jeho kariéře. Připomeneme-li si charakteristiky Waserbauerova režijního stylu a toho, jak se proměňoval v průběhu padesátých a šedesátých let, inscenace vznikla někde „na cestě“ mezi důsledným realizmem a režijním stylem „obohaceným o jevištní metaforu“. Svoji nejúspěšnější inscenaci Janáčkovy opery založil Miloš Wasserbauer na skladatelově metaforickém hledání a spatřování ,jiskry boži““ v každém člověku, jak je obvykle vzpomínáno v souvislosti s tímto Janáčkovým dílem.

K režijně interpretačním problémům i jejich vývoji v historii divadelní praxe se Wasserbauer nejednou vyjádřil - opět i v psaném textu. Jeho názory na inscenační přístup k této opeře najdeme jednak v jeho ,janáčkovských“ textech ${ }^{25}$, které se zabývají problematikou uvádění na scénu Janáčkových oper. Wasserbauer se však tomuto dílu věnoval zevrubněji v samostatné teoretické práci, která si zaslouží zvláštní pozornost, i proto že v ní režisér reflektuje interpretační scénickou praxi na obecnější úrovni. Text s názvem „Otázka soudobosti scénické interpretace Janáčkovy opery Z mrtvého domu“ byl publikován sedm let po úspěšné brněnské inscenaci, tedy v roce 1965 ve Sborniku Janáčkovy akademie múzických uměni (WASSERBAUER 1965: 75-78). ${ }^{26}$ Wasserbauer si klade otázku, v čem spočívají nové rysy scénické interpretace této opery a hlavně, v čem se mění režisérův přístup k ní. Upozorňuje, že je třeba si uvědomovat skutečnost, že se interpretace nutně vyvíjí a že není možné ustrnout v její jediné, třeba původní, podobě. Dle názoru Wasserbauera byla i Janáčkova představa o režijním výkladu opery jiná, než jakou ve své době užil sám Wasserbauer (WASSERBAUER 1965: 75). Proto v souvislosti s inscenováním Mrtvého domu ${ }^{27}$ zdůrazňuje nutnost nového výkladu díla a nové režijní koncepce, na nichž jsou ony nové rysy scénické interpretace (vždy) založeny. Mrtvý dům je pro Wasserbauera dílem, jež je nutné - více než jiné Janáčkovy opery - vždy dramaturgicky dotvářet, prohlubovat a „básnicky“ umocňovat ústřední myšlenku tohoto díla (WASSERBAUER 1965: 75). Na základě tohoto vyjádření se lze domnívat, že právě v takovém přístupu je prostor pro jevištní metaforu, k níž dle nejen našeho názoru Wasserbauer postupně dospíval. Wasserbauerovy úvahy se v tomto kontextu ubírají směrem k problematice scénografie a otázce její soudobosti či modernosti. Wasserbauer striktně odmítá povrchní, režijní koncepcí nijak opodstatněné a pouze efektní výtvarné pojetí scény. V souvislosti s tím vyslovuje požadavek koncepčního pojímání režijní i scénografické stránky inscenace, které vyrůstají z ústřední myšlenky díla:

Často se zaměňuje soudobost, modernost inscenace s použitím moderně a neobvykle výtvarně koncipované scény a jejího dekoru. Tak se také někdy stává, že režíruje vlastně talentovaný výtvarník a režisér pouze „umístuje“ operní herce do složitosti a modernosti scény. V tom nevidím naprosto žádnou modernost a soudobost scénické interpretace - nebot scéna sama o sobě, její řešení je pouze dílčí částí scénické interpretace. K výkladu díla jistě přispívá značnou mírou, ale pouze tehdy, když vyplyne z režijní koncepce, z nové, myšlenkově nové koncep-

26 V roce 1998 ji znovu otisklo odborné periodikum Opus musicum (WASSERBAUER 1998b).

27 Wasserbauer hovoří doslova o inscenování „Mrtvého domu“ - tedy bez prefixu v názvu. 
ce - a slouží jí v tom nejlepším slova smyslu. Režijní koncepce udává základní scénické řešení, které pak výtvarník realizuje svou vlastní uměleckou řečí. Obě však slouží jen k tomu, aby ústř̌ední myšlenka díla, kterou režijní koncepce má umocňovat [...] a nově vykládat a dotvářet, byla umělecky pravdivě a účinně tlumočena operními herci. (WASSERBAUER 1965: 75)

Z mrtvého domu se dle Wasserbauerova názoru liší od ostatních Janáčkových oper v několika rysech, které přestavují výzvu pro inscenátory. Předně jde o neobvyklou míru jednoty scénické stránky, respektive jednoty místa založené na tom, že se děj odehrává - kromě jedné scény lokalizované do vězeňské (vojenské nemocnice) - pouze ve věznici. Velkou rozdrobeností celku, na niž režisér rovněž upozorňuje, je míněno to, že děj sestává z vyprávění jednotlivých vězňů, což vede k epizodičnosti syžetu: „Janáček komponuje části velkého Dostojevského románu, které ho nejsilněji myšlenkově i emocionálně vzrušovaly - a řadí je zcela volně, ba útržkovitě, skoro bez dějové souvislosti vedle sebe [...].“ (WASSERBAUER 1965: 76) I přes to je však dle Wasserbauerova názoru dílo „spojeno vnitřní spojitostí tak pevně, že ústí v jednotnou myšlenku o neušlapaném lidství v člověku i za sebe strašnějších podmínek." (WASSERBAUER 1965: 76) Režisér charakterizuje tuto operu jako mozaiku. Její jednotlivé části jsou tvořeny chmurnými lidskými osudy, jejichž zobrazováním má být na scéně demonstrována přítomnost oné (janáčkovské) ,jiskry boží v každém tvoru“. Wasserbauer považuje za zcela zásadní úkol inscenace vyzvednout a doříct tuto Janáčkovu humanistickou ideu. Novou koncepci této opery spatřuje právě v oněch individuálních a současně obecných chmurných osudech, které se, jak to režisér vnímá a popisuje, vynořují ze tmy v obrysech a které jsou na chvíli ozářeny „světlým paprskem lidskosti“ (WASSERBAUER 1965: 76). Novou koncepci dále vidí v nutnosti „[h]ledat a nalézat prostředky formové i myšlenkové k vyjádření oné jiskry boží v každé z postav vězňů a k jejímu vyústění v onu širokou, mocnou touhu po svobodě, to nejbytostnější v každém živém tvoru od zvířete k člověku.“ (WASSERBAUER 1965: 76)

Wasserbauer ve svém rozboru identifikuje základní stavební prvky opery - tři monology, z nichž každý tvoří jádro jednoho dějství. Poukazuje rovněž na skutečnost, že s každým z monologů jsou svázány další epizodické děje, které „žijí samostatně, nebo dramatizují monology“ (WASSERBAUER 1965: 76). Jde ovšem o monology s velkým dramatickým potenciálem, které nejsou ani statické, ani pouze epické. Wasserbauer to připisuje Janáčkovu dramatickému cítění. Z toho plyne nutnost pojímat je dramaticky, tj. nepracovat s nimi jako s vyprávěním. Dramatičnost těchto monologů (vyprávění) je dle Wasserbauera zahrnuta již v Janáčkově libretu - v reakcích jednotlivců či sboru, které těmito monology pronikají. Tento potenciál je třeba dle Wasserbauera rozvíjet scénickou akcí a jevištními prostředky. „Monolog na jevišti se musí stát dramatickou situací.“ (WASSERBAUER 1965: 76)

Základem koncepce pojetí scény je pro Wasserbauera orel, který žije s trestanci ve věznici. Ten je chápán jako symbol touhy po svobodě. Již v Dostojevského předloze je zraněný orel, kterého chytili trestanci, líčen jako zvíře, které nemůže uvyknout vězení. Zraněný orel je ostražitý, nedovolí trestancům se k němu přiblížit. Když je později puštěn na svobodu, je to (opět již v románu) chápáno jako symbol touhy vězňů po odpírané svo- 
bodě. Právě v tomto symbolu, který je v Janáčkově libretu obzvláště zdůrazněn, spočívá i základní koncepce pojetí scény - „[...] jednoduché chmurné scény, na níž mimo nejnutnějších (ale realistických) rekvizit není nic jiného [...]. Celá scéna je [...] charakterizována a symbolizována jen náznakem ohrady předimenzovaných pylonů, otvírajících se na začátku opery po příchodu Gorjančikova do ,mrtvého domu‘ a zavírající se na konci opery pod marně vztaženýma rukama všech ostatních vězňů.“ (WASSERBAUER 1965: 76)

Wasserbauer v rámci svého rozboru nekomentuje pouze vlastní inscenaci, zaměřuje se i na některé prvky v režii Oty Zítka. Komentuje např́ílad Zítkovo scénické doslovení hudby závěru prvního dějství v Janáčkem nepředepsané herecké akci. Zítek totiž užil pantomimy vyjadřující Gorjančikův pokus zabít placmajora. Tento motiv vzpoury intelektuála Wasserbauer připisuje spíše Zítkově světovému názoru než logice Janáčkova uměleckého záměru. Wasserbauer v této souvislosti komentuje skutečnost, že hudební struktura závěru prvního dějství, v níž je akcentován motiv Skuratova, rovněž nepodporuje Zítkovo řešení. ${ }^{28}$ Wasserbauer dokonce komentuje i Vogelův výklad této části opery - výklad interpretující Skuratova jako soucitného člověka - jako nesprávný. Naproti tomu Wasserbauer vysvětluje vlastní, dle jeho postoje zřejmě logičtější pojetí této scény, u níž ostatně připouští, že pouze Janáček sám by mohl „správnou“ logiku dané pasáže vyložit. Wasserbauerova režie se tedy pokusila zdůraznit postavu Skuratova prožívajícího ve své mysli celý Lukův příběh, jehož líčení (Lukou) předchází závěru jednání. Wasserbauer odkazuje na popis scénické akce v klavírním výtahu (str. 43), v němž je u postavy Skuratova uvedeno pouze: „přichází k sobě“ (po předchozím zhroucení z bláznivého křepčení) a „zvedá se“ (WASSERBAUER 1965: 77). Do konce dějství se však již nijak neprojevuje. Právě tyto skutečnosti vedly Wasserbauerovo režijní pojetí k propojení Skuratova s Lukou, jež nabízí možný výklad Janáčkova záměru s monologem Luky a motivem Skuratova uzavírajícím dějství:

Skuratov prožívá ve své pomatené mysli intensivně celý Lukův dramatický příběh. Jemu pak přisuzujeme onu nesmyslnou větu stařičkého vězně „A umřels?“, protože jen blázen může tak reagovat. V hudební dohře, vystavěné právě na motivu Skuratova, ale námi režijně vyjádřené akcí Luky, pak Skuratov jako Lukův stín sleduje jeho každý pohyb, jako by ruku Luky, držící zbraň, vedl nepříčetný mozek Skuratovův. (WASSERBAUER 1965: 77)

Ve Wasserbauerově interpretaci tak scénickou akci sporné pasáže vede postava Luky, která je již předchozí scénickou akcí Wasserbauerovy režie úzce propojena se Skuratovem, jehož motiv je zdůrazněn v hudební složce závěru dějství. Luku totiž vnímá Wasserbauer jako velmi silnou postavu, která ochraňuje slabší, a proto on činí pokus zabít placmajova. Ve skutečnosti, že je Luka při svém pokusu o vraždu nakonec zastaven Aljejou, Wasserbauer našel další opěrný bod svého režijního pojetí opery. Aljeju vnímá a scénicky interpretuje jako onen symbol Janáčkovy ideje jiskry boží v každém člověku (WASSERBAUER 1965: 78).

V jiném svém textu (Režijné problémy interpretácie Janáčkových opier 1959: 140) se Was-

28 Připomeňme, že O. Zítek režíroval v Brně operu dvakrát - její premiéru v roce 1930 a další uvedení 1948. Obě inscenace dirigoval B. Bakala. 
serbauer vyslovuje k problematice úplného závěru opery. V brněnském provedení byla totiž z rozhodnutí dirigenta Františka Jílka použita úprava závěru ze třicátých let. Jejím autorem byl Janáčkův žák Břetislav Bakala. Wasserbauer sice považoval Janáčkův původní závěr ${ }^{29}$ za ideově správnější, avšak i tak bylo dle jeho názoru možné docílit zvýraznění správné ideje díla. Režisér „hymnický záverečný spev väzňov o slobode zámerne zarámoval údesným symbolom neúprosne sa zatvárajúcich väzenských vrát, medzi gigantickými pylónmi ktorých väzni vztahujú ruky po slobode - ruky, ktoré prosia i hrozia zároveň." ${ }^{30}$ (WASSERBAUER 1959: 140) Wasserbauer vyjádřil názor, že právě takto scénicky domyšlená a zvýrazněná idea ve srovnání s původním Janáčkovým závěrem vyzněla mnohem jasněji a otřesněji (WASSERBAUER 1959: 140).

Wasserbauer upozorňuje, že Janáček $\mathrm{v}$ této své opeře mnohé nedořekl a že je $\mathrm{v}$ jeho hudbě mnohem více, než do ní sám vědomě vložil. Právě tato skutečnost je pro Wasserbauera základem inscenační výzvy, kterou pro něho opera $Z$ mrtvého domu představuje. Janáčkova hudba z pohledu režiséra v sobě skrývá myšlenkové a emocionální bohatství, které musí být nalezeno a scénicky dosloveno, aby scénická interpretace (inscenace) této opery mohla být náležitě nová a „soudobá“ (WASSERBAUER 1965: 78).

K problematice interpretace Janáčkových oper se vyslovil i Walter Felsenstein, jehož pochvalná slova o Wasserbauerově režii $Z$ mrtvého domu otiskly Hudebni rozhledy (FELSENSTEIN 1958: 925). Felsenstein upozorňuje na úspornost a hutnost Janáčkovy hudební řeči, které mohou působit posluchači, obzvláště neníli na ni „zvyklý“, při vnímání jisté potíže. Podle Felsensteina je totiž běžný posluchač zvyklý na spíše pasivní vnímání hudby. Felsenstein proto oceňuje skutečnost, že Janáček posluchače nutí brát na vědomí i obsah hudby, ,protože každý její takt, každý její tón je bezprostřední výpovědí“ (FELSENSTEIN 1958: 925). Hovoří doslova o „plasticitě“ a zřetelnosti, na něž musí být kladen důraz v každé inscenaci Janáčkovy opery, aby byla podnícena posluchačova pozornost, př́padně vzbuzen zájem slyšet dílo znovu, a tím ho i poznávat. Poznávat ho právě v oné interpretační zřetelnosti a plasticitě. Těmi Felsenstein mínil „pokud možno obecně srozumitelné líčení a vyjádření všeho toho, co stojí za slovy a za orchestrálním zvukem. Tedy žádnou povrchní inscenaci, jež pečuje jen o hladký vnější dějový průběh, nýbrž inscenaci, jež jde do hloubky, za povrch věci a jež opravdu přispívá k porozumění hudby.“ (FELSENSTEIN 1958: 925) Splnění právě těchto kvalit přičítá Wasserbauerově režii brněnské inscenace z roku 1958, když ji v tomto smyslu označuje za „vzorové provedení“.

Wasserbauer shrnuje problematiku inscenování oper Leoše Janáčka slovy: „Inscenovat Janáčka znamená znát dokonale život ve všech jeho projevech, ale umět se na něj podívat očima umělce právě tak osobitého jako jím byl sám Janáček.“ (WASSERBAUER 1957:

29 V době brněnské inscenace byla opera inscenována i v pražském Národním divadle. Wasserbauer poukazuje na skutečnost, že v Praze na rozdíl od brněnského provedení užili inscenátoři Janáčkovy verze závěru opery. Pravděpodobně jde o odkaz na inscenaci v režii Hanuše Theina a pod taktovkou Jaroslava Vogela (premiéra 10. 5. 1958).

30 Autorem scény byl Wasserbauerův ,janáčkovský“ spolupracovník František Tröster. 
213) O Janáčkových operách mluví Wasserbauer často doslova jako o „dramatických dílech“ a o Janáčkovi jako o „dramatikovi“. V kontextu inscenování jeho děl zdůrazňuje nutnost „porozumět a proniknout jeho zkratkovitým a nedořečeným hudebním výrazem a dotvářet ho scénicky tak pravdivě a nekonvenčně, jak pravdivý a nekonvenční je Janáčkův komposiční sloh.“" (WASSERBAUER 1957: 213)

\section{Závěr}

Pojem realistické interpretace v operní inscenaci se pro Wasserbauerovu generaci stal klíčovou teoretickou otázkou. Často byl diskutován v souvislosti s jevištním ztvárněním oper Leoše Janáčka či v kontextu přístupu k operám minulých staletí, jež byly původně inscenovány ve stylu, jenž byl specifický pro dobu jejich vzniku. Z Wasserbauerových úvah vyplývá, že nejde o snahu přiblížit se v inscenačním stylu dané opery realizmu jako slohu konce 19. století. Jedná se spíše o přístup k dílu jako celku, především v oblasti hledání jeho významu či sdělení a ve způsobu, jímž jsou při jevištní interpretaci komunikovány.

Požadavek vycházení z partitury pak určuje služebnou či podřazenou roli inscenačního týmu ve vztahu autor (autoři) opery a inscenace. Partitura slouží jako kodex, který musí být respektován. Cokoliv inscenátoři učiní, má být ve prospěch efektivního prezentování myšlenek a záměrů autorů operního díla - a to včetně citové či emoční náplně.

$\mathrm{V}$ této studii jsme se zaměřili na teoretickou stránku problematiky realistické jevištní interpretace v opeře. Jaký měly tyto teoretické požadavky dopad na dobovou inscenační tvorbu, bude již předmětem jiné studie. Avšak je třeba podotknout, že se vycházení z partitury, požadavek realistické, „věrné“ či „pravdivé“ interpretace, nebo také ctění ideje díla, v kontextu teoretických diskuzí zaměřených na přístup k inscenování oper objevuje i dnes. Představuje zásadní názor, který reprezentuje jeden ze základních operně inscenačních principů, jehož platnost je opakovaně diskutována.

\section{Bibliografie}

BARTOŇKOVÁ, Olga. 1980. Miloš Wasserbauer a opera dvacátého století [Miloš Wasserbauer and the 20th-century Opera]. In Sbornik Janáčkovy akademie múzických uměni v Brně 7 (1980): 115.

BARVÍK, Miroslav. 1952. Učme se ze sovětského vzoru. K provedení opery D. Kabalevského „Tarasova rodina“ na československých operních scénách [Let Us Learn From Soviet Model]. Hudebni rozhledy V (1952): 20: 4-10.

BĚLINSKIJ, Vissarion Grigorjevič. 1956. Hamlet, Shakespearovo drama. Močalov v úloze Hamleta [Hamlet, a Drama by Shakespeare. Močalov as Hamlet]. In Vissarion Grigorjevič Bělinskij. Spisy V. G. Bělinského I. Stati a recense 1834-1840 [Works by V. G. Bělinski I. Papers and Reviews]. Praha: Státní nakladatelství krásné literatury, hudby a umění, 1956: 449-574. 
BURJANEK, Josef. 1952a. K československé premiéře Mladé gardy v Brně [To the Czechoslovak Premiere of the Mladá garda in Brno]. Hudebni rozhledy V (leden 1952): 1: 9-10.

BURJANEK, Josef. 1952b. Brněnské provedení Mejtusovy Mladé gardy [Brno Production of Mladá garda]. Hudebni rozhledy V (1952): 20: 18-20.

BURJANEK, Josef. 1970. Za Milošem Wasserbauerem (1907-1970) [An Obituary for Miloš Wasserbauer (1907-1970)]. Program Státního divadla v Brně (ř́ijen 1970): 3-8.

DUFKOVÁ, Eugenie a Bořivoj SRBA (edd.). 1984. Postavy brněnského jeviště: umělci Národního, Zemského a Státniho divadla v Brně. I, 1884-1984 [Who Is Who in Brno Theatre: Národní, Zemské and Státní Theatre in Brno I., 1884-1984]. Brno: Státní divadlo, 1984.

DUFKOVÁ, Eugenie a Bořivoj SRBA (edd.). 1985-1989. Postavy brněnského jeviště: umèlci Národniho, Zemského a Státního divadla v Brně. II, 1884-1989 [Who Is Who in Brno Theatre: Národní, Zemské and Státní Theatre in Brno II., 1884-1989]. Brno: Státní divadlo, 1985-1989.

DUFKOVÁ, Eugenie a Bořivoj SRBA (edd.). 1994. Postavy brněnského jevištěe: umělci Národního, Zemského, Státního a Národniho divadla v Brně: český divadelni slovnik. III, 1884-1994 [Who Is Who in Brno Theatre: Národní, Zemské and Státní Theatre in Brno III., 1884-1994]. Brno: Národní divadlo, 1994.

FELSENSTEIN, Walter. 1958. K interpretaci Janáčkových oper [A Note to the Interpretation of Janáček’s Operas]. Hudebni rozhledy XI (1958): 22: 925.

HAVLÍČKOVÁ KYSOVÁ, Šárka a Helena SPURNÁ. 2017. Realismus hudebního divadla Waltera Felsensteina - pravda, nebo mýtus? [Realism in Music Theatre of Walter Felsenstein. The Truth, ort he Myth?]. Theatralia 20 (2017): 1: 88-121.

HAVLÍČKOVÁ KYSOVÁ, Šárka. 2016. Rozhovor s Eugenii Dufkovou. [Audio záznam pořízený dne 16. 3. 2016 na divadelní oddělení MZM; Interview With Eugenie Dufková. An Audiorecording From 16 March, 2016, Theatre Department, Moravian Museum, Brno]. Brno, 2016.

HILMERA, Jiří. 1989. Operní režie Miloše Wasserbauera [Opera Productions By Miloš Wasserbauer]. In id. František Tröster. Praha: Divadelní ústav, 1989: 161-178.

JANÁČKOVÁ, Olga. 1984. Miloš Wasserbauer. In Eugenie Dufková a Bořivoj Srba (edd.) 1984. Postavy brněnského jeviště: umělci Národního, Zemského a Státního divadla v Brně I, 1884-1984 [Who Is Who in Brno Theatre: Národní, Zemské and Státní Theatre in Brno I., 1884-1984]. Brno: Státní divadlo, 1984: 504-508.

KŘÍŽ, František. 1985-1989. In Eugenie Dufková a Bořivoj Srba (edd.). 1985-1989. Postavy brněnského jeviště: umèlci Národniho, Zemského a Státního divadla v Brně. II, 1884-1989 [Who Is Who in Brno Theatre: Národní, Zemské and Státní Theatre in Brno I., 1884-1984]. Brno: Státní divadlo, 1985-1989.

PEČMAN, Rudolf. 1964. O opeře s Milošem Wasserbauerem [Talking About Opera With Miloš Wasserbauer]. Hudebni rozhledy 17 (1964): 185-187.

POLEDŇÁKOVÁ, Eugenie. 1965. Režisér Miloš Wasserbauer [Miloš Wasserbauer, a Director]. Program Státního divadla v Brně (květen 1965): 4-5.

Pozůstalost M. Wasserbauera [Miloš Wasserbauer's Estate], oddělení dějin divadla Moravského zemského muzea, karton č. 280.

TELCOVÁ, Jiřina. 1965. Scénografie „Příhod lišky Bystroušky“ [Stage Design to "Liška Bytsrouška”. Časopis Moravského musea 50 (1965): 261-282. 
TELCOVÁ, Jiřina. 1966. Scénografie Káti Kabanovy [Stage Design to Káta Kabanová]. Časopis Moravského musea 51 (1966): 345-363.

TONCROVÁ, Dana. 2000. Miloš Wasserbauer a jeho hledání realistické interpretace v opeře. Tuorba Miloše Wasserbauera ve Státním divadle Brno v letech 1958-1970 [Miloš Wasserbauer and His Search for Realistic Staging of Opera. Work of Miloš Wasserbauer in Státní divadlo Brno in 1958-1970]. Brno. Masarykova univerzita. Diplomová práce, nepublikováno.

WASSERBAUER, Miloš. 1952. Naše práce na „Tarasově rodině“ D. Kabalevského [Our Collaboration on The Taras Family by D. Kabalevski]. Program 7 (1952): 16-17.

WASSERBAUER, Miloš. 1957. Princip realistické scénické interpretace v opeře [Principles of Realistic Staging in Opera]. Divadlo 8 (1957): 8: 211-214.

WASSERBAUER, Miloš. 1959. Režijné problémy interpretácie Janáčkových opier [Issues in Directing Operatic Pieces by Janáček]. Slovenské divadlo 7 (1959): 2: 135-143.

WASSERBAUER, Miloš. 1965. Otázka soudobosti scénické interpretace Janáčkovy opery Z mrtvého domu [How to Stage Janáček's Z mrtvého domu In an Up-to-date Way]. In Sbornik Janáčkovy akademie múzických uměni 5 (1965): 75-78.

WASSERBAUER, Miloš. 1998a. Janáčkovské vyznání režiséra Miloše Wasserbauera [Miloš Wasserbauer's Profession for Janáček]. Opus musicum 30 (1998): 4-5: 147-150.

WASSERBAUER, Miloš. 1998b. Otázka soudobosti scénické interpretace Janáčkovy opery „Z mrtvého domu“ [How to Stage Janáček's Z mrtvého domu In an Up-to-date Way]. Opus musicum 30 (1998): 4-5: 151-155. 


\section{Mgr. Šárka Havlíčková Kysová, Ph.D.}

Masaryk University, Brno, Czech Republic

E-mail: sarka.havlicek@mail.muni.cz

Šárka Havlíčková Kysová získala titul Ph.D. na Masarykově univerzitě v Brně v roce 2010, kde obhájila disertační práci s názvem Hastábhinaja. Gesta rukou v tradičním divadelním umění Indie. V letech 2009 až 2012 vyučovala teorii divadla na Katedře divadelních, filmových a mediálních studií Univerzity Palackého v Olomouci. V letech 2011 až 2015 se podílela na Masarykově univerzitě na řešení dvou projektů; „Český divadelní strukturalismus: souvislosti a potenciál" a "Operační program vzdělávání pro konkurenceschopnost - 2.2 Vysokoškolské vzdělávání". Od roku 2012 pracuje jako odborná asistentka na Katedře divadelních studií Masarykovy university.

Ve svém výzkumu i v pedagogické činnosti se zaměřuje na teorii divadla se zvláštním zřetelem k možnosti uplatnění kognitivních teorií v teatrologii. Zabývá se také inscenační praxí opery a tradičním indickým divadlem kúdijáttam. Od roku 2015 vede výzkumný projekt s názvem "Generace režiséra Miloše Wasserbauera a progresivní dramaturgie v opeře Státního divadla v Brně", který je zaměřen na výzkum operní inscenační praxe ve druhé polovině 20. století (projekt GAČR, GA15-06548S).

Šárka Havlíčková Kysová received her PhD from Masaryk University, Brno in 2010 with the doctoral thesis Hastaabhinaya. Hand gestures in traditional theatre art of India. From 2009 to 2012 she taught theatre theory at Palacký University in Olomouc. From 2011 to 2015 she worked on two Masaryk University research projects; 'Czech Structuralist Thought on Theatre: Context and Potency' and 'Operational Programme Education for Competitiveness - 2.2 Higher Education'. Since 2012 she has worked as assistant professor at the Department of Theatre Studies at Masaryk University.

In her research and teaching, she focuses on theatre theory with an emphasis on the cognitive approach in theatre studies. She also specialises in opera staging and the traditional Indian theatre form - Kootiyattam. Since 2015 she has lead the research project 'Generation of Miloš Wasserbauer, the theatre director, and progressive dramaturgy of State Theatre in Brno' which is focused on operatic productions in Brno in the second half of the 20th century (supported by the Czech Science Foundation project No. GA15-06548S). 